\title{
PENGOLAHAN SAMPAH RUMAH TANGGA BERBASIS PARTISIPASI AKTIF DARI MASYARAKAT MELALUI PENERAPAN METODE 4Rp UNTUK MENGHASILKAN KOMPOS
}

\author{
Buhani $^{{ }^{*}}$, Riko Noviadi ${ }^{2}$, Suharso $^{1}$ \\ ${ }^{1}$ Jurusan Kimia FMIPA Universitas Lampung, Jl. Prof. Soemantri Brojonegoro No. 1 Bandar Lampung, 35145 \\ ${ }^{2}$ Jurusan Peternakan Politeknik Negeri Lampung, Jl. Soekarno Hatta No. 10 Rajabasa Bandar Lampung \\ Penulis Korespodensi: buhani@fmipa.unila.ac.id
}

\begin{abstract}
Abstrak
Dalam rangka mengimplementasikan kegiatan pengelolaan dan pengolahan sampah berbasis partisipasi masyarakat, Universitas Lampung, Pemkab Way Kanan, dan perguruan tinggi mitra yaitu Politeknik Negeri Lampung membentuk pilot project pengelolaan sampah berbasis masyarakat. Pengelolaan sampah berbasis masyarakat bertujuan untuk menerapkan konsep 4Rp (Reduce, Reuse, Recycle, Replace, Participation) melalui Program Kemitraaan Wilayah (PKW) Kemeristekdikti, sehingga sampah/limbah pertanian dapat dikelola secara mandiri oleh masyarakat di tingkat sumbernya langsung, dan dapat mengurangi jumlah timbulan sampah yang harus dikelola di TPS atau TPA, serta dapat memberikan nilai tambah secara ekonomi. Kegiatan ini telah dilaksanakan di desa yang memiliki potensi sampah/limbah perkebunan dan pertanian di Desa Way-Tuba kecamatan Gunung Labuhan Kabupaten Way Kanan. Secara umum, hasil kegiatan tersebut telah meningkatkan partisipasi dan pengetahuan masyarakat terhadap paradigma tentang sampah dan pengelolaan sampah dengan konsep 4Rp, pengadaan pupuk/kompos secara mandiri, serta menjadi pelopor pengelolaan sampah berbasis partisipasi aktif dari masyarakat dengan persentase rata-rata peningkatan dari 38,6 menjadi $86 \%$.
\end{abstract}

Kata kunci : Pengelohan sampah, Metode 4RP, Kompos

\section{Pendahuluan}

Kabupaten Way Kanan adalah salah satu dari kabupaten/kota di Propinsi Lampung yang memiliki luas wilayah $3.921 .63 \mathrm{~km}^{2}$ atau sebesar $11,11 \%$ dari luas Propinsi Lampung. Untuk mewujudkan program peningkatan produktivitas perkebunan dan pertanian, maka pemerintah kabupaten (Pemkab) Way Kanan berupaya melibatkan masyarakat sebagai mitra. Salah satu upaya tersebut dilakukan melalui pemanfaatan sampah rumah tangga, limbah perkebunan dan pertanian yang diolah sebagai kompos untuk menciptakan kemandirian masyarakat terhadap kebutuhan pupuk organik dan mengurangi ketergantungan terhadap pupuk sintetik dalam rangka meningkatkan produktivitas perkebunan dan pertanian.

Program pengelolaan sampah/ limbah di Kabupaten Way Kanan telah dimulai sejak awal tahun 2015, yaitu pengolahan sampah di permukiman masyarakat dengan adanya inisiasi dari pemkab Way Kanan melalui Dinas Lingkungan Hidup (LH) Kabupaten Way Kanan yang meluncurkan program Bank sampah. Program Pemkab tersebut dilaksanakan melalui pengadaan bank sampah (Tribun Lampung, 2016 dan Antara Lampung, 2016).

Program bank sampah bertujuan agar masyarakat yang sebagian besar bermata pencaharian di bidang perkebunan dan pertanian dapat secara mandiri memiliki kemampuan mengolah dan memanfaatkan limbah/sampah menjadi kompos sebagai pupuk dalam meningkatkan produktivitas usaha mereka. Program tersebut mencakup kegiatan ekonomi/lapangan usaha yang berhubungan dengan pengelolaan berbagai bentuk limbah/sampah, seperti limbah/sampah rumah tangga, perkebunan, 
SAKAI SAMBAYAN — Jurnal Pengabdian kepada Masyarakat

dan pertanian yang dapat mencemari lingkungan. Hasil dari proses pengelolaan limbah/sampah tersebut akan dijadikan input dalam produksi lainnya. Program ini sangat didukung oleh kepala daerah pemkab Way Kanan yang dimulai dari penerapan Bank sampah serta pengelolaan sampah untuk dijadikan pupuk kompos (Tribun Lampung, 2016). Beberapa kecamatan yang telah menerapkan Bank sampah ini, antara lain Kecamatan Blambangan Umpu di desa Sidoarjo dan Kampung Pisangbaru, Kecamatan Bumiagung (Antara Lampung, 2016).

Akan tetapi karena program tersebut baru dimulai, maka program tersebut belum berjalan sesuai rencana. Rendahnya partisipasi masyarakat terhadap program ini menjadi salah satu kendala. Sebagai kabupaten yang baru berkembang, maka Kabupaten Way Kanan belum memiliki Tempat Penampungan Akhir (TPA) yang memadai. Sampah yang berasal dari aktivitas rumah tangga, pasar serta limbah perkebunan dan pertanian biasanya dibuang langsung tanpa pengolahan bahkan sebagian besar limbah dari perkebunan dan pertanian dibakar. Hal ini tentu saja akan menimbulkan dampak negatif berupa pencemaran lingkungan dengan adanya proses pembakaran yang akan meningkatkan kadar gas $\mathrm{CO}_{2}$ bahkan gas $\mathrm{CO}$ atau gas-gas lain yang sangat berbahaya bagi kesehatan manusia dan lingkungan (Buhani dkk.,2017; Buhani dkk. 2010; Suharso dkk., 2010; Sembiring dkk., 2009).

Sampah yang tidak dikelola dengan baik sering terlihat dibiarkan bertumpuk di tempattempat terbuka, dibuang ke sungai, ke selokan, atau dibakar. Banyak masyarakat juga yang masih berperilaku membuang sampah sembarangan baik di jalanan mau pun di lingkungan tempat tinggalnya. Sampah yang tidak dikelola menyebabkan dampak negatif baik langsung mau pun tidak langsung bahkan dapat mengakibatkan pencemaran lingkungan oleh bahan kimia toksik baik berupa senyawa organik maupun anorganik seperti logam berat (Buhani dkk. 2010; Buhani dkk. 2006; Buhani dkk., 2015; Suharso dan
Buhani, 2011; Buhani dkk., 2012; Buhani dkk., 2011) Dampak negatif langsung diantaranya lingkungan menjadi kumuh, kotor, menimbulkan bau tak sedap dan berpotensi menjadi sumber penyakit yang akan berdampak bagi kesehatan warga. Kebiasaan masyarakat untuk membuang sampah ke saluran air atau sungai menyebabkan saluran tersumbat dan pendangkalan sungai sehingga menyebabkan banjir pada saat musim hujan merupakan contoh negatif tidak langsung. Sebagai contoh, banjir besar yang semakin sering terjadi berbagai wilayah merupakan contoh nyata karena banyaknya sampah yang tidak tertangani. Sungai-sungai di diperkotaan seperti Jakarta, Surabaya (Tarmizi, 2013), dan juga Bandar Lampung (Hidayat, 2010) terindikasi telah tercemar sampah domestik. Sampah yang dibuang ke sungai dan akhirnya bermuara ke laut juga berpotensi menimbulkan pencemaran lingkungan kawasan pesisir yang kaya akan sumber daya alam. Air yang keluar dari timbulan sampah (lindi) juga telah terbukti sebagai salah satu sumber polutan organik yang berbahaya bagi kesehatan dan menimbulkan pencemaran pada air sumur, air tanah dan sungai. Sementara sampah plastik menjadi hal yang penting karena sebagian besar wadah yang digunakan dalam aktivitas manusia terbuat dari plastik sedangkan plastik sendiri merupakan bahan yang tidak mudah terurai di lingkungan, memerlukan waktu lama sampai puluhan tahun untuk dapat terdekomposisi.

Oleh karena itu diperlukan upaya untuk meningkatkan partisipasi masyarakat dalam pengelolaan sampah dengan mereduksi sampah di sumbernya seperti yang berasal dari rumah tangga atau limbah perkebunan dan pertanian. Dalam rangka mengimplementasikan kegiatan tersebut, Universitas Lampung, Pemkab Way Kanan, dan perguruan tinggi mitra yaitu Politeknik Negeri Lampung membentuk pilot project pengelolaan sampah berbasis masyarakat melalui Program Kemitraan Wilayah (PKW) dari Kemenristekdikti. Pengelolaan sampah berbasis masyarakat bertujuan untuk menerapkan konsep 4Rp (Reduce, Reuse, 
SAKAI SAMBAYAN — Jurnal Pengabdian kepada Masyarakat

Recycle, Replace, Participation) melalui PKW dari Kemenristekdikti, sehingga sampah/limbah dapat dikelola secara mandiri oleh masyarakat di tingkat sumber, dan dapat mengurangi jumlah timbulan sampah yang harus dikelola di TPS atau TPA, serta dapat memberikan nilai tambah secara ekonomi.

Kegiatan ini telah dilaksanakan di desa yang memiliki potensi sampah/limbah rumah tangga atau perkebunan dan pertanian seperti di Desa Way-Tuba kecamatan Gunung Labuhan Kabupaten Way Kanan. Secara umum, hasil kegiatan tersebut telah meningkatkan partisipasi dan pengetahuan masyarakat terhadap paradigma tentang sampah dan pengelolaan sampah dengan konsep 4Rp, pengadaan pupuk/kompos secara mandiri, serta menjadi pelopor pengelolaan sampah berbasis partisipasi aktif dari masyarakat.

\section{Bahan dan Metode}

Bahan yang digunakan meliputi bahan-bahan yang umum digunakan untuk pembuatan kompos sedangkan morfologi dan konstituen unsur kompos ditentukan menggunakan scanning electron microscopy-energy dispersive- $X$ ray (SEM-EDX) (Zeiss MA10).

Metode kegiatan dilakukan melalui beberapa tahapan meliputi: sosialisasi kegiatan, pembentukan kelembagaan, dan tahap pengolahan sampah.

\section{A. Tahap sosialisasi kegiatan}

Pada tahap ini ide pengelolaan sampah mandiri disosialisasikan terlebih dulu kepada pengurus RT/RW, tokoh masyarakat, tokoh agama, dan organisasi kemasyarakatan lainnya sebelum di lanjutkan ke masyarakat. Kemudian dilanjutkan dengan kegiatan yang berkaitan dengan teknis penggunaan peralatan serta perlengkapan yang ada, seperti tempat penampungan sampah organik, kantong untuk sampah plastik, kertas dan kaca (PKKc), serta tempat sampah campursari. Kegiatan sosialisasi dilanjutkan dengan pembentukan organisasi informal oleh dan untuk masyarakat yang akan menjadi pilot project. Fungsi dari organisasi ini adalah menjalankan pengelolaan sampah. Organisasi ini memiliki sejumlah kader yang bertugas memberikan penyuluhan, pendampingan, maupun pengawasan dalam menerapkan konsep pengelolaan sampah berbasis masyarakat.

\section{B. Tahap pelaksanaan pengelolaan sampah}

Kegiatan ini dimulai dari: (a) pemilahan sampah yang merupakan kegiatan berupa aktivitas memisahkan dan mengelompokkan sampah sesuai dengan jenis sampah. Kegiatan ini dilakukan oleh warga di masing-masing rumah tangganya. Pemilahan sampah disesuaikan dengan kelompok sampah yang sudah disepakati pada saat sosialisasi kegiatan; (b) teknik pengomposan: sampah organik dimasukkan ke dalam tong komposter yang telah diberikan atau dibuat dan dibagikan ke masyarakat. Sampah organik yang berukuran besar dicacah terlebih dulu baru kemudian dimasukkan ke komposter. Komposter kemudian ditutup. Untuk mempercepat pengomposan, setiap hari dapat diberikan MOL (mikroorganisme lokal) yang dibuat sendiri, atau starter lain yang sudah jadi. Penambahan agen starter ini membuat teknik pengomposan menjadi lebih cepat, tidak berbau, dan mudah. Penambahan sampah organik dapat dilakukan sampai komposter penuh.

\section{Monitoring dan Evaluasi}

Kegiatan pemantauan dan evaluasi merupakan kegiatan yang sangat penting dalam sebuah program kegiatan. Pemantauan dan evaluasi dilakukan dalam rangka mengetahui sejauh mana program telah dilaksanakan sesuai dengan rencana. Agar arah program tetap berjalan sesuai dengan tujuan program. Evaluasi juga dilakukan untuk mengetahui tingkat minat atau perhatian peserta pada pelaksanaan kegiatan.

Evaluasi kegiatan dilakukan dengan tujuan untuk mengetahui tingkat minat atau perhatian peserta pada pelaksanaan kegiatan. Evaluasi 
SAKAI SAMBAYAN — Jurnal Pengabdian kepada Masyarakat

kegiatan dilakukan dengan mengadakan pre-test dan post-test untuk membandingkan beberapa parameter ukur yang meliputi tentang peningkatan minat, pengetahuan, kemampuan, kesadaran, dan ketrampilan peserta untuk mengolah sampah berdasarkan konsep 4Rp. Sebelum kegiatan penyuluhan dan praktik dilakukan serangkaian pre test untuk mengetahui pemahaman peserta terhadap beberapa pertanyaan yang diajukan berkaitan dengan pengelolaan dan pengolahan sampah. Beberapa pertanyaan pre test sekaligus menjadi pertanyaan post test dalam rangka membandingkan hasil kegiatan penyuluhan disusun sesuai dengan Tujuan Intruksional Khusus (TIK) yang ingin dicapai dalam kegiatan ini seperti yang tertera dalam Tabel 1.

Tabel 1. Komposisi TIK pada Pre dan Post test

\begin{tabular}{|l|l|c|}
\hline No & \multicolumn{1}{|c|}{ TIK } & Butir Soal \\
\hline 1. & $\begin{array}{l}\text { Pengetahuan terhadap } \\
\text { jenis-jenis sampah }\end{array}$ & 1,2 \\
\hline 2. & $\begin{array}{l}\text { Pengetahuan terhadap } \\
\text { pengolahan sampah }\end{array}$ & 3,4 \\
\hline 3. & $\begin{array}{l}\text { Pengetahuan terhadap } \\
\text { penting pengelolaan } \\
\text { sampah }\end{array}$ & 5,6 \\
\hline 4. & $\begin{array}{l}\text { Pengetahuan tentang } \\
\text { manfaat kompos }\end{array}$ & 7,8 \\
\hline 5. & $\begin{array}{l}\text { Pengetahuan cara } \\
\text { pembuatan kompos dari } \\
\text { sampah organik }\end{array}$ & 9,10 \\
\hline
\end{tabular}

\section{Hasil dan Pembahasan}

Kegiatan PKW yang telah dilakukan pada kelompok masyarakat di desa Way Tuba kecamatan Gunung Labuhan telah mendapatkan apresiasi yang sangat baik dari masyarakat untuk mengolah sampah menjadi kompos. Adapun produk kompos yang dihasilkan seperti yang ditampilkan pada Gambar 1.

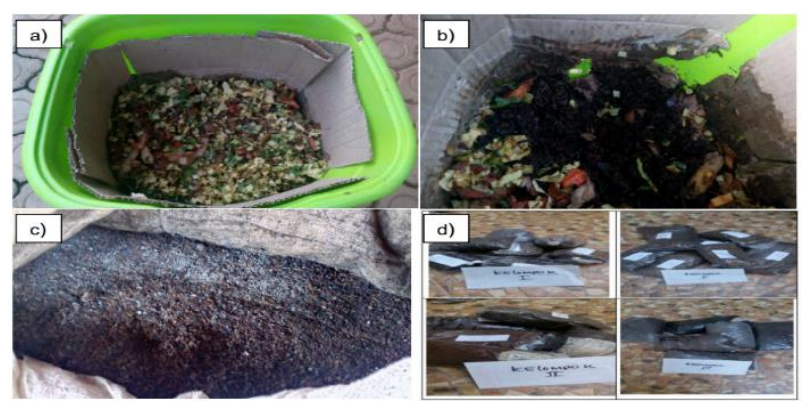

Gambar 1. a) sampah rumah organik rumah tangga, b) kompos setengah jadi, c) dan d) kompos yang dihasilkan dari beberapa kelompok masyarakat.

Hasil pengolahan sampah berbasis partisipasi masyarakat pada kegiatan ini berupa produk kompos (Gambar 1) dan hasil analisisnya dengan menggunakan scanning electron microscopy- energy dispersive-X ray (SEM-EDX) yang ditampilkan pada Gambar 2. Berdasarkan hasil analisis menggunakan SEM (Gambar 2a) dapat diamati bahwa morfologi permukaan kompos bersifat homogen (Buhani dkk., 2012a ) sedangkan hasil analisis dengan EDX menunjukkan bahwa kompos mengandung unsur-unsur hara yang penting bagi pertumbuhan tanaman. Analisis menggunakan EDX bersifat semi kuantitatif, dengan kata lain hanya menunjukkan konsitituenkonstituen unsur yang terdapat dalam kompos (Buhani dkk., 2017 ). Dari hasil analisis dengan EDX, dapat diamati bahwa kompos yang dihasilkan dari limbah masyarakat telah mengandung unsur-unsur yang diperlukan bagi pertumbuhan tanaman.

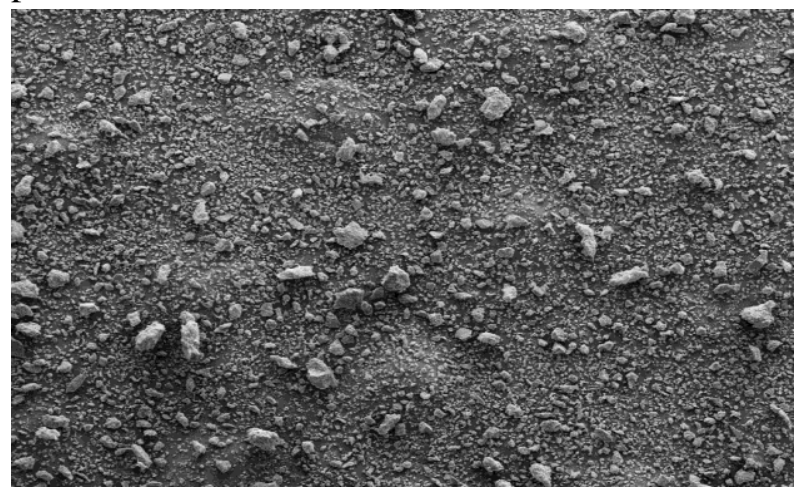

(a) 
SAKAI SAMBAYAN — Jurnal Pengabdian kepada Masyarakat

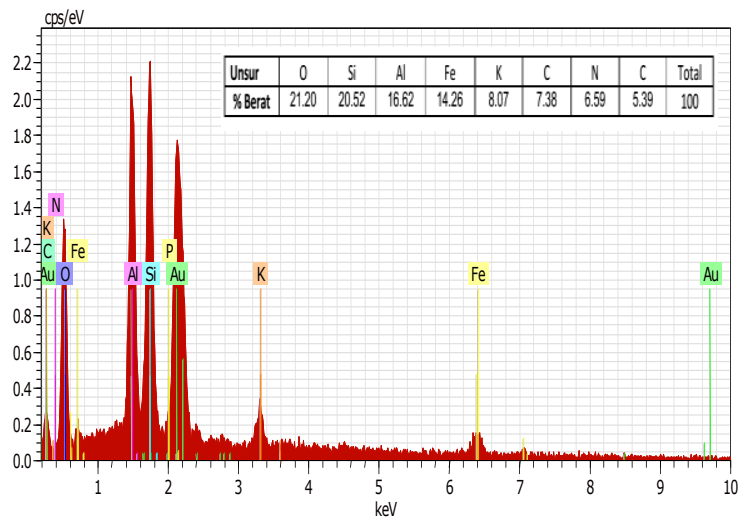

(b)

Gambar 2. SEM-EDX kompos dari sampah rumah tangga

Kegiatan ini juga telah meningkatkan kesejahteraan masyarakat melalui peningkatan pendapatan, produktivitas, dan kesehatan dengan terlaksananya kegiatan pengelolaan sampah berbasis partisipasi masyarakat (Radar Lampung, 2017). Hasil kegiatan ini berupa produk kompos yang dapat dimanfaatkan secara langsung sebagai pupuk bagi tanaman (Gambar 3) Adanya kegiatan ini telah menambah pendapatan masyarakat dengan cara mengurangi biaya belanja sayuran dan juga biaya pembelian pupuk (Buhani dkk., 2017a). Selain itu, adanya kegiatan pengelolaan sampah telah menciptakan lingkungan yang sehat dan bersih sehingga meningkatkan kesehatan masyarakat.

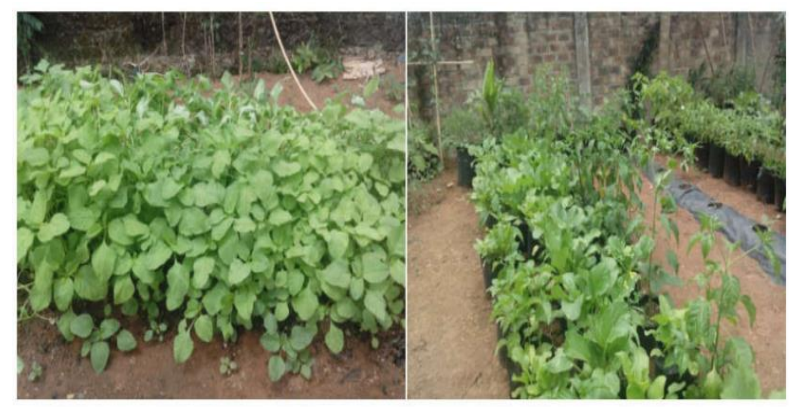

Gambar 3. Dokumentasi contoh hasil kegiatan masyarakat dalam pemanfaatan kompos dari pengolahan sampah organik yang digunakan sebagai pupuk pada kebun sayur di pekarangan rumah

Berdasarkan hasil monitoring dan evaluasi yang telah dilakukan, maka capaian kegiatan PKW ini antara lain terjadinya peningkatan kualitas pemahaman dan kesadaran masyarakat terhadap paradigma pengelolaan sampah berbasis partisipasi masyarakat yang mendukung peningkatan daya saing wilayah, melalui peningkatan sumber daya wilayah seperti peningkatan pengelolaan tanaman pertanian dan perkebunan.

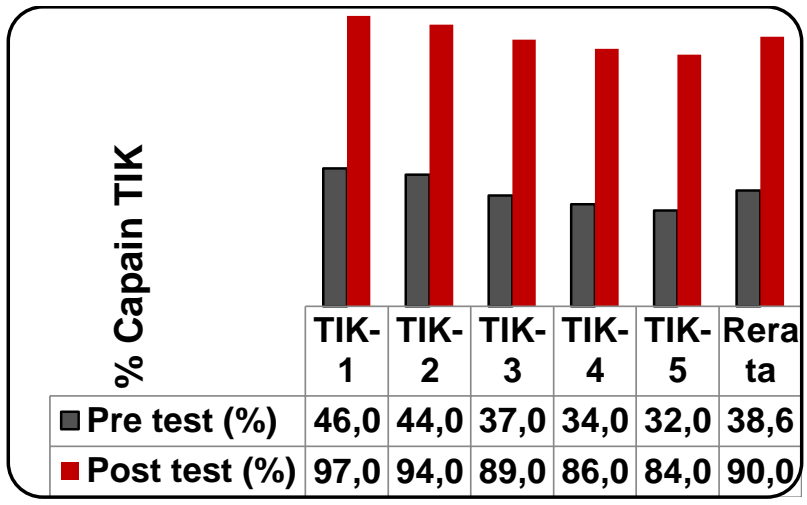

Gambar 4. Perbandingan hasil pencapaian TIK pada pre dan post test

Hasil analisis kuesioner yang diperoleh menunjukkan bahwa secara umum, kegiatan ini telah meningkatkan partisipasi dan pengetahuan masyarakat terhadap paradigma tentang sampah dan pengelolaan sampah dengan konsep 4Rp, pengadaan pupuk/kompos secara mandiri, serta menjadi pelopor pengelolaan sampah berbasis partisipasi aktif dari masyarakat dengan persentase rata-rata peningkatan dari 38,6 menjadi $86 \%$ (Gambar 4). Pada Gambar 4 dapat diamati bahwa secara umum dari semua komponen TIK pada pengetahuan awal peserta sebelum kegiatan pengabdian dilakukan adalah sekitar 38,60\%. Hal ini menunjukkan bahwa sebenarnya peserta sudah memiliki pengetahuan dasar tentang pengelolaan dan pengohan sampah, terutama tentang pengetahuan umum peserta terhadap jenis-jenis sampah dan dampaknya terhadap lingkungan (Buhani dkk., 2017b). Setelah dilakukan kegiatan PKW ini, terjadi rerata peningkatan dari semua komponen TIK sebesar 51,40\%. Data tesebut mengindikasikan bahwa kegiatan ini telah berhasil meningkatkan pengetahuan mitra dalam memahami dan menyadari serta telah menerapkan pengelolaan dan pengolahan sampah. 
SAKAI SAMBAYAN — Jurnal Pengabdian kepada Masyarakat

\section{Kesimpulan}

Secara umum, kegiatan PKW telah meningkatkan pemahaman dan kesadaran masyarakat terhadap paradigma pengelolaan sampah berbasis partisipasi masyarakat yang akan mendukung peningkatan daya saing wilayah, melalui peningkatan sumber daya wilayah seperti peningkatan pengelolaan tanaman pertanian dan perkebunan. Kegiatan PKW ini juga telah berdampak terhadap peningkatan kesejahteraan masyarakat melalui peningkatan pendapatan, produktivitas, dan kesehatan dengan terlaksananya kegiatan pengelolaan sampah berbasis partisipasi masyarakat. Hasil kegiatan ini berupa produk kompos yang dapat dimanfaatkan secara langsung sebagai pupuk bagi tanaman. Selain itu, adanya kegiatan pengelolaan sampah telah menciptakan lingkungan yang sehat dan bersih sehingga meningkatkan kesehatan masyarakat.

\section{Ucapan Terima Kasih}

Terima kasih disampaikan kepada Direktorat Riset dan Pengabdian Masyarakat Kemenristekdikti (No. Kontrak 549/UN26.21/KU/2017) dan Pemkab Way Kanan yang telah mendanai keberlangsungan kegiatan PKW serta Politeknik Negeri Lampung atas kerja samanya.

\section{Daftar Pustaka}

Antara Lampung. (2016). http://www.antaralampung.com/berita/289513/ka bupaten-waykanan-akan-bentuk-banksampah.Diakses pada tanggal 01 April 2016.

Badan Pusat Statistik Propinsi Lampung, 2014.

Badan Pusat Statistik Kabupaten Way Kanan, 2014.

Buhani, Suharso, Noviadi, R. (2017). PKW Penerapan metode 4Rp dalam Mendukung Pengelolaan dan Pengolahan Sampah Berbasis Partisipasi Masyarakat di Kabupaten Way Kanan. Laporan Tahunan PKW. Universitas Lampung.
Buhani, Narsito, Nuryono, Kunarti, E.S., Suharso. (2015). Adsorption Competition of $\mathrm{Cu}$ (II) Ion in Ionic Pair and Multi-Metal Solution by Ionic Imprinted Amino-Silica Hybrid Adsorbent. Desalination and Water Treatment, 55(5), 12401252.

Buhani, Noviadi, R., Suharso, Alkautsar, R., Anggraini M., Hidayah, T. (2017). Pengolahan Limbah Pertanian Berbasis Partisipasi Aktif dari Masyarakat Melalui Penerapan Metode 4RP untuk Meningkatkan Pengadaan Pupuk Secara Mandiri. Seminar Nasional Pengembangan Teknologi Pertanian : Bandar Lampung, Polinela.

Buhani, Suharso. (2009). Immobilization of Nannochloropsis sp Biomass by Sol-Gel Technique as Adsorbent of Metal Ion $\mathrm{Cu}$ (II) from Aqueous Solutions. Asian Journal of Chemistry, 21(5), 3799-3808.

Buhani, Suharso, Satria, H. (2011). Hybridization of Nannochloropsis sp Biomass-Silica through SolGel Process to Adsorb Cd (II) Ion in Aqueous Solutions. European Journal of Scientific Research, 51(4), 467-476.

Buhani, Suharso, Aprilia, L. (2012). Chemical Stability and Adsorption Selectivity on $\mathrm{Cd}^{2+}$ Ionic Imprinted Nannochloropsis Sp Material with Silica Matrix from Tetraethyl Orthosilicate. Indonesian Journal of Chemistry, 12(1), 94-99.

Buhani, Suharso, Sembiring, Z. (2006). Biosorption of Metal Ions $\mathrm{Pb}$ (II), $\mathrm{Cu}$ (II), and $\mathrm{Cd}$ (II) on Sargassum Duplicatum Immobilized Silica Gel Matrix. Indonesian Journal of Chemistry, 6(3), 245-250.

Buhani, Suharso, Sumadi. (2012a). Production of Ionic Imprinted Polymer from Nannochloropsis sp. Biomass and Its Adsorption Characteristics toward $\mathrm{Cu}$ (II) Ion in Solutions. Asian Journal of Chemisty, 24 (1), 133-140.

Buhani, Suharso, Sumadi. (2010). Adsorption Kinetics and Isotherm of $\mathrm{Cd}$ (II) Ion on Nannochloropsis sp Biomass Imprinted Ionic Polymer. Desalination, 259 (1-3), 140-146. 
SAKAI SAMBAYAN — Jurnal Pengabdian kepada Masyarakat

Buhani, Musrifatun, Pratama, D.S., Suharso, Rinawati. (2017). Modification of Chaetoceros sp. Biomass with Silica-Magnetite Coating and Adsorption Studies towards Cu(II) Ions in Single and Binary System. Asian Journal of Chemistry ,29 (12), 2734-2739.

Hidayat, D. (2010). Kajian Sebaran Logam Berat Pb dan Cd di Muara Sungai Way Kuala Bandar Lampung. Laporan Penelitian DIPA PNBP Unila.

Kementrian Lingkungan Hidup. (2012). Profil Bank Sampah. Rapat Kerja Nasional Bank Sampah. Malang.

Kementerian Negara Lingkungan Hidup (KNLH) Republik Indonesia. 2008. Statistik Persampahan Indonesia. Jakarta

RPJMD Kabupaten Way Kanan 2016-2021, Blambangan Umpu, April 2016.

Radar Lampung, 2017, Terapkan Metode 4Rp di Way Kanan untuk Mendukung Pengelolaan Sampah Berbasis Partisipasi Warga, 13 Oktober 2017.

Sembiring, Z., Buhani, Suharso, Sumadi. (2009).
Isoterm Adsorpsi ion $\mathrm{Pb}$ (II), $\mathrm{Cu}$ (II) dan $\mathrm{Cd}$ (II) pada Biomassa Nannochloropsis sp yang Dienkapsulasi Akuagel Silika. Indonesian Journal of Chemistry, 9(1), 1-5.

Suharso, Buhani. (2011). Biosorption of Pb (II), Cu (II) and $\mathrm{Cd}$ (II) from Aqueous Solution Using Cassava Peel Waste Biomass. Asian Journal of Chemistry, 23(3), 1112-1116.

Suharso, Buhani, Sumadi. (2010). Immobilization of $S$. Duplicatum Supported Silica Gel Matrix and Its Application on Adsorption-Desorption of $\mathrm{Cu}$ (II), Cd (II) and Pb (II) Ions. Desalination, 263 (1-3), 64-69.

Tarmizi,

$\mathrm{T}$.

(2014).

http://www.antaranews.com/berita/367264/62-

persen-pencemaran-kali-surabaya-limbahdomestik. Diakses pada tanggal 20 Pebruari 2014.

Tribun Lampung. (2016). Adipati: Way Kanan Siap Aktif Berperan Kurangi Sampah. Minggu, 21 Februari 2016.

Way Kanan Dalam Angka (WKDA). (2015). Blambangan Umpu. 